\title{
Organizational Socialization and Its Relation with Organizational Performance in High Schools
}

\author{
Ali Balci ${ }^{1}$, Inci Ozturk ${ }^{2}$, Mahmut Polatcan ${ }^{2}$, Ahmet Saylik $^{2}$, Erkut Bil ${ }^{2}$ \\ ${ }^{1}$ Professor, Ankara University Faculty of Educational Sciences, Ankara, Turkey \\ ${ }^{2}$ Ankara University Institute of Educational Sciences, Ankara, Turkey \\ Correspondence: Mahmut Polatcan, Ankara University Institute of Educational Sciences, Ankara, 06590, Turkey.
}

Received: June 26, 2016 Accepted: April 8, $2016 \quad$ Online Published: June 21, 2016

doi:10.11114/jets.v4i9.1685 URL: http://dx.doi.org/10.11114/jets.v4i9.1685

\begin{abstract}
This study is designed to explore organizational socialization and organizational performance levels of secondary school teachers and the relation between the two variables mentioned. The study is designed as correlational research. The target population of the research consists of 5744 teachers who work in public and private Anatolian high schools in the center of Ankara, the capital city of Turkey. Using the stratified sampling technique, 650 participant teachers have been included in the sample. This study has revealed that the participants are relatively more socialized in the organizational socialization language factor, which is followed by socialization levels in the following factors: performance proficiency, people, history, organizational goals and values, and politics. The socialization levels of teachers indicate significant differences in the history and language factors according to gender. In all the factors, the participant private school teachers are found to be more socialized than the public school teachers. Their organizational performance levels significantly vary according to gender and type of school. The performance of teachers in private schools is relatively higher than that of those in public schools. There is a significant, moderate positive relation between organizational socialization and organizational performance.
\end{abstract}

Keywords: teacher socialization, teacher performance, school

\section{Introduction}

Socialization, a research area of organizational behaviour (Okon, Frank, \& Antigha, 2012), is substantially a learning process (Van Maanen, 1975; Ostroff \& Kozlowki, 1992). In most general terms, it is a process of passing values and knowledge down to next generations (Van Maanen \& Schein, 1979). In other words, socialization is a process of transferring a given social culture to youth by adult members of the society. Without doubt, the process largely involves education and teaching and is fulfilled by educational organizations. On the other hand, organizational socialization is basically a learning process of employees through which they learn what tasks they are obliged to do, and how to do these tasks as well as team work (Feldman, 1988; Van Maanen, 1975; Van Maanen, 1978). It is also associated with individual attitudes and responses to their professional experiences in the organization (Feldman, 1976), and with adaptation to their organizational roles and enthusiasm about content and clues in role taking (Chao, O'Leary- Kelly, Wolf, Klein, \& Gardner, 1994; Schein, 1990; Taormina, 2009; Van Maanen, 1978; Van Maanen \& Schein, 1979).

The organizational socialization literature indicates that the pioneer researchers analysed the socialization process of newcomers in an organization (Feldman, 1976; Porter, Lawler \& Hackman, 1975; Reichers, 1987; Van Maanen \& Schein, 1979; Wanous, 1980). In addition, they focused on the newcomers' quest for information and feedback in the organization (Ashforth \& Saks, 1996; Bauer, Morrison \& Callister, 1998; Chao et al., 1994; Ostroff \& Kozlowski, 1992). Later, socialization researchers tended towards socialization factors, content and learning during socialization (Chao et al., 1994; Feldman, 1981). Reichers (1987) stated that social research has focused on particular situational factors such as socialization strategies, working traits and group norms. Taormina (2009) suggested that in the early studies of socialization, the former researchers attached less importance to human needs, whereas the latest authors in the field have ignored employee motivation, with a strong emphasis of employee behaviour.

Organizational socialization highlights the development of both organizations and individuals as part of an interactive process. Naturally, organizational needs and expectations are accompanied by individual information and skills development, role taking behaviours and adaptation to organizational norms and values (Feldman, 1976; Van Maanen \& 
Schein, 1979). An employee who is able to socialize automatically contributes to a given organization to attain organizational goals. On the other hand, one with a low level of organizational socialization will suffer from lack of motivation and commitment and job dissatisfaction, and thus turnover rate will increase (Saks \& Ashforth, 1997; Smith, 1989).

During the socialization process, the themes suggested by Van Maneen and Schein (1979), Feldman (1981), Fisher (1986), have influenced the development of socialization factors. Besides the themes, goals, values and role assignments form the basis of the content in the field of socialization.

Later, comprehensive studies on the content of socialization contributed much to the development of different factors of socialization. Chao et al. (1994) discuss socialization in six factors: performance proficiency, people, politics, language, organizational goals and values, and history. Taormina (2004) introduces a new perspective to organizational socialization content and divides the socialization approach into four categories. These are education, interpretation, support of colleagues and future expectations.

Schools are instructional organizations that provide education. Thus, socialization processes of organizations and schools are generally parallel. Shareholders of school socialization process are principally administrators, teachers and students, who lead to change and transformation, and school environment. The socialization process involves organizational and professional socialization. Professional socialization, known as professional initialization stage for educational administrators, generally consists of administrator training programmes and in-service training programmes. According to Norton (1994), school administrators give conservative or innovative responses to organizational socialization. Role acceptance by school administrators brings the former, while job changes introduced by them mean the latter (cited by Balc1, 2003). It is obvious that organizational socialization of administrators springs in school environment where s/he is employed. Similarly, professional socialization of teachers generally involves pedagogical education they receive in university programmes. Organizational socialization of teachers, built upon their official appointment to school, develops through teacher-director, teacher-student and teacher-environment interactions as well as in-service training programmes (Balc1, 2003).

Performance, the secondary significant concept in the research, could be described as total endeavour to attain a particular goal. In the literature, performance, with regard to function, is associated with the terms "efficiency", "productivity" and, "output" and is viewed as a result of the interaction between individual talent and motivation (Torrington \& Hall, 1995). On the other hand, organizational performance, which could be considered as an indispensable part of organizations and the main reason of organizational survival, is total output of an employee as a result of a certain process, including job attitudes and organizational behaviour (Yanfei, Xi, \& Fantiani, 2011). Organizational performance is employee contribution level to attain organizational goals (Johns \& Saks, 2005). The performance evaluation process, a critical decision making instrument, especially for human resources units, caters for organizational needs by serving as a tool with which one can understand whether organizational goal attainment is fulfilled or not. Robbins (2005) suggests that human resources decisions are made, training needs of employees are explored, employees are provided with feedback on organizational goal attainment degree, and a basis of rewarding system is built with performance evaluation. Accordingly, Wiese and Buckley (1998) emphasize that performance evaluation plays an active role in employee development and is crucial for objectivity in decisions of redundancy, promotions and downgrading in job position or status change and career goal setting and goal pursuit.

Performance of educational staff particularly that of teachers, is hard to decide and describe as teacher performance does not only consist of professional tasks at school. Perhaps, what they do out of school is more influential in performance than school work. The following are time-consuming, meticulous obligations for teachers: course planning, reading numerous sources rather than textbooks, feedback on student assignments, writing essays or school bulletin and seminar studies. Therefore, it is not easy to determine and measure the performance of a teacher. Apart from performance measuring instruments, validity and reliability of performance measurement process is essential to decide teacher performance level precisely (Yanfei, Xi, \& Fantiani, 2011). However, as in other professions, expected teacher performance levels seem to be directly associated with a satisfactory socialization experience, school/job commitment, job satisfaction and security.

The research has indicated that there is a relationship between organizational socialization and employee performance. QianYing (2004) has concluded that behavioural performance of employees (job satisfaction, organizational commitment) has a great influence on organizational socialization. Xu Ke (2008) has shown that that employee socialization has considerable, positive effects on performance (cited by Wang, He and Zeng, 2011). The research findings which indicate that organizational socialization has positive effects on performance are significant in practice. Developing professional skills of employees with the help of organizational socialization process, thus increasing performance, accelerates organizational adaptation. 
As it is clear, acceleration of socialization process of employees has become a critical issue for organizations and academia in order to increase individual and organizational performance. Many researchers today suggest that organizational socialization levels of employees have a significant, positive effect on employee performance (Yanfei, $\mathrm{Xi}$, \& Fantiani, 2011).

The measurable aims of the research that analyzes the relationship between organizational socialization level and teacher performance are given below;

1. What are organizational socialization levels and organizational performance levels of teachers?

2. Do organizational socialization levels and organizational performance levels of teachers vary according to the following?

- Gender

- Type of School

- Seniority

- Postgraduate Education teachers?

3. Is there a relationship between organizational socialization levels and organizational performance levels of

4. To what extent do organizational socialization levels of teachers predict their organizational performance?

\section{Method}

\subsection{Research Design}

The research had the survey design, with an aim to explore organizational socialization levels and organizational performance levels of secondary school teachers and the relationship between the two variables in views of the teachers.

\subsection{Research Population and Sample}

The target population of the research consisted of 5744 teachers employed in public and private Anatolian high schools in the center of Ankara, the capital city of Turkey. In the research, "stratified sampling" technique, a probability based sampling method, was used to represent the target population. The main reason for the stratified sampling in the study was to represent subpopulations in the sample and lower the cost of the research (Balc1, 2013). In this context, the target population of the research was divided into nine stratums by district for both public and private Anatolian High Schools. The nine central district schools were listed and it was ensured that the sampling represents the subgroups, in consideration with the rate of subpopulation in the overall population. With the stratified sampling technique, a sampling of 650 participants was finally decided to be included in application as a result of the sampling size calculations (Balc1, 2013), taking the number of teachers employed in public and private Anatolian High Schools into consideration.

\subsection{Data Gathering Instruments}

Upon official permission, a scale developed by Chao, O'Leary-Kelly, Wolf, Klein and Gardner (1994) was adapted to Turkish and employed to explore teacher socialization levels. The Organizational Socialization Scale consists of 34 items and the following six factors: history, language and politics, organizational goals and values, people and organizational performance. The scale is a five point Likert type (completely disagree, disagree, partially agree, agree, completely agree).

The 22-item "Individual Performance Evaluation Form for Academic Staff and Faculty", developed by Wharton County Junior College (2000), was adapted and employed to explore organizational performance levels of the participant teachers. The individual performance evaluation form is a five point Likert type scale (completely disagree, disagree, partially agree, agree, completely agree). The validity and reliability analysis results of the original scale have not been available despite all endeavours by the authors.

Exploratory Factor Analysis (EFA) and Confirmatory Factor Analysis (CFA) were incorporated to test the construct validity of the organizational socialization and organizational performance scales. Cronbach Alpha reliability coefficient and corrected item total correlation were calculated to test the reliability of the two scales.

\section{Data Analysis}

Principal components factor analysis was applied to 34 items to test the six factors. Based on the Kaiser criterion, six factors were extracted, accounting for $41,72 \%$. Kaiser value was found 0.75 and factor loadings ranged from 0.28 to 0.81. 28 items were kept in the "Organizational Socialization Scale". The reliability of the six factors, as measured by Cronbach Alpha coefficient, was acceptable with estimations greater than or equal to 0.60 . The scale reliability, as 
measured by Cronbach Alpha coefficient, was found acceptable with the estimation equal to 0.90. Corrected item total correlation ranged from 0.37 to 0.55 . Principal components factor analysis was applied to 21 items to test organizational performance. Based on the Kaiser criterion, accounting for $42,5 \%$, Kaiser value was found 0.89 and factor loadings ranged from 0.39 to 0.79. 21 items were kept in the "Individual Performance Evaluation Form for Faculty". The scale reliability, as measured by Cronbach Alpha coefficient, was found acceptable with the estimation equal to 0.92 . Corrected item total correlation ranged from 0.37 to 0.76 .

The data were analyzed by SPSS. T-test and one-way analysis of variance were used to determine whether the teachers' views about organizational socialization and organizational performance varied according to various demographic variables. Correlation analysis was employed to test relationships between organizational socialization and organizational performance. Regression analysis was performed to predict organizational performance (dependent variable), taking organizational socialization factors as independent variables.

\section{Findings}

The secondary school teachers had high socialization levels in all the socialization factors. The participants relatively had the highest level of socialization in the language factor $(\bar{X}=4,41)$, which was respectively followed by performance proficiency (PP) $(\bar{X}=4,39)$, people $(\bar{X}=4,14)$, history $(\bar{X}=4,09)$, organizational goals and values $(\bar{X}=4,08)$ and politics $(\bar{X}=4,00)$.

In the history factor, the mostly agreed item was "I am not familiar with the traditions, rituals, ceremony and celebrations of my organization/school." $(\bar{X}=4,33)$. On the other hand, the least agreed item was "I am familiar with the history of my school." ( $\bar{X}=3,93$ ). In the language factor, the most and the least agreed items were respectively; "I understand the specific meanings of professional jargon and words (e.g. acquisition, target behaviour, constructivism, cooperative learning etc.)." ( $\bar{X}=4,47)$ and "I know most job related abbreviations and acronyms [e.g. BT (Board of Teachers), GRC [Guiding Research Centre and DNE (Directorate of National Education)].” ( $\bar{X}=4,33)$. In the factor of policies, the most agreed item was "I know who are the most efficient professionals in school" $(\bar{X}=4,16)$, and the least agreed item was "I have found out how this school actually works". $(\bar{X}=3,80)$. In the factor of people, the most agreed item was "I am considered to be a team member in my study group." ( $\bar{X}=4,54)$. And the least agreed item was "I am quite popular in school." ( $\bar{X}=3,55)$. In the factor of organizational goals and values, the most agreed item was "I understand the goals of my school." $(\bar{X}=4,30)$. In this factor, the least agreed item was "I don't always believe in the values (in academic/artistic/sporting fields) established by my organization." ( $\bar{X}=3,69)$. In the factor of performance proficiency, the most agreed item was "I have qualifications to perform professionsl tasks." $(\bar{X}=4,61)$. The least agreed item was "I have not been able to learn the subtleties of my occupation." $(\bar{X}=4,28)$.

The mean value of the teachers organizational performance has been calculated as 4,33 out of 5, which was considerably high. The most agreed three items were respectively: "I encourage an atmosphere of mutual respect and kindness" $(\bar{X}=4,64)$, "I abide by class hour schedules" $(\bar{X}=4,58)$, "I give examples when suitable; I express concepts and ideas and make explanations in other manners." $(\bar{X}=4,58)$. The least agreed items were: "I make contact information accessible to all students (I share my working hours, phone number and e-mail address)" $(\bar{X}=4,07)$, "I encourage contact/interaction (I recommend students to call me, send me e-mails or set an appointment with me)" $(\bar{X}=$ 4,06) and "I expect a high level of academic performance" ( $\bar{X}=3,48)$. T-test, ANOVA, correlation and multiple regression values of organizational socialization and organizational performance item-total of the participants are presented in Table 1, Table 2, Table 3, Table 4, Table 5 and Table 6. 
Table 1. T-Test Results of Organizational Socialization Factors According to Gender, Type of School and Post Graduate Education

\begin{tabular}{|c|c|c|c|c|c|c|c|c|}
\hline Variable & & Grade & $\mathbf{N}$ & $\bar{X}$ & Ss & df & $\mathbf{T}$ & $\mathbf{p}$ \\
\hline \multirow{12}{*}{ 离 } & \multirow{2}{*}{ History } & Female & 439 & 16,75 & 9,43 & 654 & 2,457 & .01 \\
\hline & & Male & 217 & 16,21 & 9,16 & & & \\
\hline & \multirow{2}{*}{ Language } & Female & 439 & 8,96 & 4,45 & 654 & 1,994 & .04 \\
\hline & & Male & 217 & 8,77 & 4,68 & & & \\
\hline & \multirow{2}{*}{ Politics } & Female & 439 & 24,25 & 13,15 & 654 & 0,304 & .76 \\
\hline & & Male & 217 & 24,34 & 13,24 & & & \\
\hline & \multirow{2}{*}{ People } & Female & 439 & 16,74 & 8,60 & 654 & 0,086 & .93 \\
\hline & & Male & 217 & 16,75 & 8,80 & & & \\
\hline & \multirow{2}{*}{$\begin{array}{l}\text { Organizational } \\
\text { Goals\& Values }\end{array}$} & Female & 439 & 28,99 & 15,69 & 654 & 0,414 & .67 \\
\hline & & Male & 217 & 28,84 & 15,56 & & & \\
\hline & \multirow{2}{*}{ PQ } & Female & 439 & 22,30 & 11,07 & 654 & 1,828 & .06 \\
\hline & & Male & 217 & 21,88 & 11,17 & & & \\
\hline \multirow{12}{*}{ 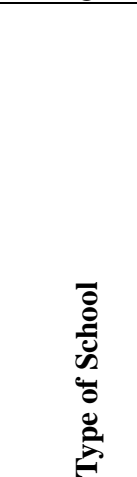 } & \multirow{2}{*}{ History } & Public & 376 & 16,05 & 9,31 & 654 & 5,976 & .00 \\
\hline & & Private & 280 & 17,26 & 9,15 & & & \\
\hline & \multirow{2}{*}{ Language } & Public & 376 & 8,70 & 4,60 & 654 & 5,157 & .00 \\
\hline & & Private & 280 & 9,16 & 4,32 & & & \\
\hline & \multirow{2}{*}{ Politics } & Public & 376 & 23,44 & 12,73 & 654 & 7,138 & .00 \\
\hline & & Private & 280 & 25,37 & 13,20 & & & \\
\hline & \multirow{2}{*}{ People } & Public & 376 & 16,32 & 8,79 & 654 & 5,647 & .00 \\
\hline & & Private & 280 & 17,29 & 8,23 & & & \\
\hline & \multirow{2}{*}{$\begin{array}{l}\text { Organizational } \\
\text { Goals\& Values }\end{array}$} & Public & 376 & 27,77 & 15,10 & 654 & 8,437 & .00 \\
\hline & & Private & 280 & 30,43 & 15,45 & & & \\
\hline & \multirow{2}{*}{ PQ } & Public & 376 & 21,79 & 11,11 & 654 & 4,016 & .00 \\
\hline & & Private & 280 & 22,66 & 10,95 & & & \\
\hline \multirow{12}{*}{ 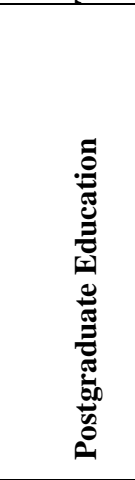 } & \multirow{2}{*}{ History } & Yes & 228 & 16,65 & 9,33 & 654 & 0,542 & .58 \\
\hline & & No & 428 & 16,54 & 9,38 & & & \\
\hline & \multirow{2}{*}{ Language } & Yes & 228 & 9,01 & 4,56 & 654 & 1,833 & .06 \\
\hline & & No & 428 & 8,84 & 4,51 & & & \\
\hline & \multirow{2}{*}{ Politics } & Yes & 228 & 24,45 & 13,32 & 654 & 0,877 & .38 \\
\hline & & No & 428 & 24,19 & 13,09 & & & \\
\hline & \multirow{2}{*}{ People } & Yes & 228 & 16,78 & 8,98 & 654 & 0,306 & .75 \\
\hline & & No & 428 & 16,72 & 8,49 & & & \\
\hline & \multirow{2}{*}{$\begin{array}{l}\text { Organizational } \\
\text { Goals\& Values } \\
\end{array}$} & Yes & 228 & 29,00 & 16,36 & 654 & 0,296 & .76 \\
\hline & & No & 428 & 28,90 & 15,23 & & & \\
\hline & \multirow{2}{*}{ PQ } & Yes & 228 & 22,18 & 11,17 & 654 & 0,121 & .90 \\
\hline & & No & 428 & 22,15 & 11,08 & & & \\
\hline
\end{tabular}

In Table 1, organizational socialization levels of the secondary school teachers were examined according to gender. In the organizational history, there were significant differences according to gender $\left[\mathrm{t}_{(654)}=2,457 ; \mathrm{p}<.05\right]$. It was remarkable that the female teachers' socialization level $(\bar{X}=16,75)$ was higher than that of the male participants $(\bar{X}$ $=16,21)$ in this factor. Similarly, it was observed that the participants' socialization levels varied according to gender in the language factor $\left[\mathrm{t}_{(654)}=1,994 ; \mathrm{p}<.05\right]$. As a result, the female teachers' socialization level $(\bar{X}=8,96)$ was higher than that of the male participants $(\bar{X}=8,77)$ in the language factor. There were no significant differences in the factor of politics $\left[\mathrm{t}_{(654)}=0,304 ; \mathrm{p}>.05\right]$, people $\left[\mathrm{t}_{(654)}=0,086 ; \mathrm{p}>.05\right]$, organizational goals and values $\left[\mathrm{t}_{(654)}=0,414 ; \mathrm{p}>.05\right]$ and performance proficiency $\left[\mathrm{t}_{(654)}=1,828 ; \mathrm{p}>.05\right]$ according to gender.

The participants' organizational socialization levels significantly varied according to type of school (Table 1). In the history factor, the private school teachers considered socialization level important $(\bar{X}=17,26)$, when compared to the public school teachers $(\bar{X}=16,05)$. Similarly, significant differences were observed in language $\left[\mathrm{t}_{(654)}=5,157 ; \mathrm{p}<.05\right]$, politics [ $\left.\mathrm{t}_{(654)}=7,138 ; \mathrm{p}<.05\right]$, people [ $\left.\mathrm{t}_{(654)}=5,647 ; \mathrm{p}<.05\right]$, organizational goals and values $\left[\mathrm{t}_{(654)}=8,437 ; \mathrm{p}<.05\right]$ and performance proficiency $\left[\mathrm{t}_{(654)}=4,016 ; \mathrm{p}<.05\right]$ in favor of the private school teachers.

There were no significant differences in the organizational socialization factors according to postgraduate education. It was observed that there were no differences in history $\left[\mathrm{t}_{(654)}=0,542 ; \mathrm{p}>.05\right]$, language $\left[\mathrm{t}_{(654)}=1,833 ; \mathrm{p}>.05\right]$, politics $\left[\mathrm{t}_{(654)}=0,877 ; \mathrm{p}>.05\right]$, people $\left[\mathrm{t}_{(654)}=0,306 ; \mathrm{p}>.05\right]$, organizational goal and values $\left[\mathrm{t}_{(654)}=0,296 ; \mathrm{p}>.05\right]$ and performance proficiency $\left[\mathrm{t}_{(654)}=0,121 ; \mathrm{p}>.05\right]$. 
Table 2. ANOVA Test Results of Organizational Socialization Factors According to Seniority

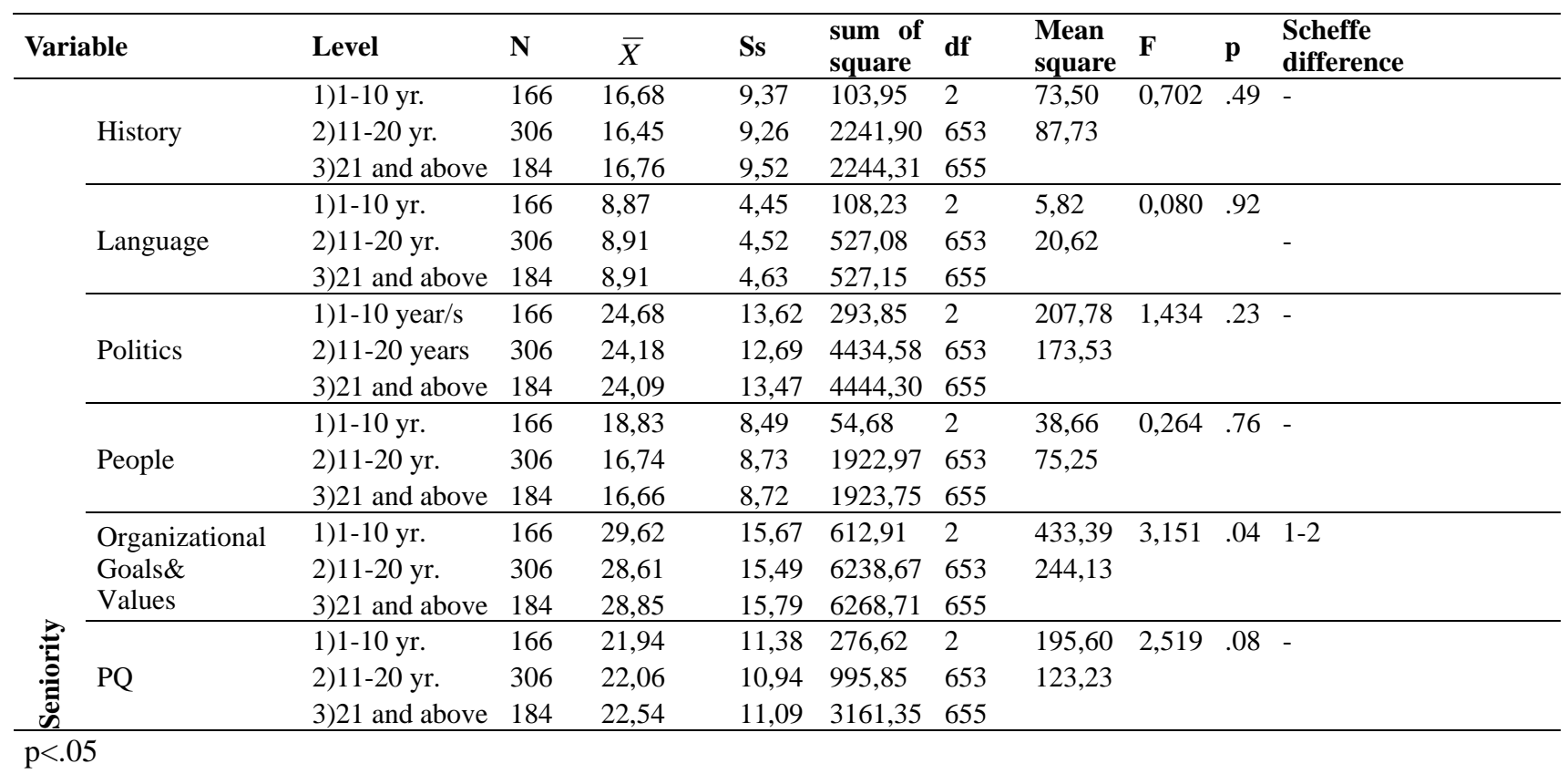

As shown in Table 2, The participant teachers' views about organizational goals and values varied according to seniority $\left[\mathrm{F}_{(2-653)}=3,151 ; \mathrm{p}<.05\right]$. Scheffe Test was applied to determine group differences. According to the results of Scheffe test, the performance of the teachers with professional experience of 1-10 years was higher than that of those with professional experience of 11-20 years. Therefore, it could be suggested that the more the professional experience is, the less importance is given to organizational targets and values. There were no differences in history $\left[F_{(2-653)}=0,702\right.$; $\mathrm{p}>.05]$, language $\left[\mathrm{F}_{(2-653)}=0,080 ; \mathrm{p}>.05\right]$, politics $\left[\mathrm{F}_{(2-653)}=1,434 ; \mathrm{p}>.05\right]$, people $\left[\mathrm{F}_{(2-653)}=0,264 ; \mathrm{p}>.05\right]$ and performance proficiency $\left[\mathrm{F}_{(2-653)}=2,519 ; \mathrm{p}>.05\right]$ according to seniority.

Table 3. T-Test Results of Organizational Performance According to Gender, Type of School, Postgraduate Education

\begin{tabular}{|c|c|c|c|c|c|c|c|c|}
\hline Variable & & Grade & $\mathbf{n}$ & $\bar{X}$ & Ss & df & $\mathbf{T}$ & $\mathbf{p}$ \\
\hline \multirow{2}{*}{ Gender } & Organizational & Female & 439 & 92,21 & 41,980 & 654 & 2,192 & .02 \\
\hline & Performance & Male & 217 & 90,45 & 41,99 & & & \\
\hline \multirow{2}{*}{$\begin{array}{l}\text { Type } \\
\text { School }\end{array}$} & Organizational & Public & 376 & 89,59 & 42,29 & 654 & 6,402 & .00 \\
\hline & Performance & Private & 280 & 94,30 & 40,17 & & & \\
\hline \multirow{2}{*}{$\begin{array}{l}\text { Postgraduate } \\
\text { Education }\end{array}$} & Organizational & Yes & 228 & 92,44 & 42,91 & 654 & 1,583 & .11 \\
\hline & Performance & No & 428 & 91,19 & 41,52 & & & \\
\hline
\end{tabular}
$\mathrm{p}<.05$

As shown in Table 3, the participant teachers' organizational performance level significantly varied according to gender $\left[\mathrm{t}_{(654)}=2,192 ; \mathrm{p}<.05\right]$. The female teachers had higher performance level $(\bar{X}=92,21)$ than that of the male participants $(\bar{X}=90,45)$. Significant differences were observed in the participants' organizational performance levels $\left[\mathrm{t}_{(654)}=6,402 ; \mathrm{p}\right.$ $<.05]$ according to type of school. The private school teachers' performance $(\bar{X}=94,30)$ were relatively higher than that of the public school teachers $(\bar{X}=89,59)$. The teachers' performance levels did not significantly vary according to postgraduate education $\left[\mathrm{t}_{(654)}=1,583 ; \mathrm{p}>.05\right]$.

Table 4. ANOVA Test Results of Organizational Performance According to Seniority

\begin{tabular}{|c|c|c|c|c|c|c|c|c|c|c|c|}
\hline \multicolumn{2}{|c|}{ Variable } & \multirow{2}{*}{$\begin{array}{l}\text { Level } \\
\text { 1)1-10 yr/s. }\end{array}$} & \multirow{2}{*}{$\begin{array}{l}\mathbf{N} \\
166 \\
\end{array}$} & \multirow{2}{*}{$\begin{array}{c}\bar{X} \\
93,10\end{array}$} & \multirow{2}{*}{$\begin{array}{l}\text { Ss } \\
40,32 \\
\end{array}$} & \multirow{2}{*}{\begin{tabular}{|l|}
$\begin{array}{l}\text { Sum of } \\
\text { square }\end{array}$ \\
4764,72 \\
\end{tabular}} & \multirow{2}{*}{$\begin{array}{l}\text { df } \\
2 \\
\end{array}$} & \multirow{2}{*}{\begin{tabular}{|l|}
$\begin{array}{l}\text { Mean } \\
\text { square }\end{array}$ \\
3369,17 \\
\end{tabular}} & \multirow{2}{*}{$\begin{array}{l}\mathbf{F} \\
3.661 \\
\end{array}$} & \multirow{2}{*}{$\begin{array}{l}\mathbf{p} \\
.02\end{array}$} & \multirow{2}{*}{$\begin{array}{l}\begin{array}{l}\text { difference } \\
\text { (Scheffe) }\end{array} \\
1-2 \\
\end{array}$} \\
\hline$:=$ & & & & & & & & & & & \\
\hline$\overline{0}$ & Organizational & 2)11-20 yr. & 306 & 90,60 & 43,17 & 44998,46 & 653 & 1760,92 & & & \\
\hline$\stackrel{\bar{N}}{\infty}$ & & 3)21 and above & 184 & 92,08 & 41,23 & 45250,02 & & & & & \\
\hline
\end{tabular}

In Table 4, organizational performance of the teachers $\left[\mathrm{F}_{(2-653)}=3,661 ; \mathrm{p}<.05\right]$ showed significant differences according to seniority. Scheffe test was applied to determine whether there was a significant difference between the groups. According to the results of the Scheffe test, the performance of those with professional experience of 1-10 years was higher than that of those with professional experience of 11-20 years. Thus, it could be suggested that teachers with less experience attach more importance to organizational performance than seniors. 
Table 5. Results of Correlation Analysis of Organizational Socialization and Organizational Performance

\begin{tabular}{|c|c|c|c|c|c|c|c|c|}
\hline & 1 & 2 & 3 & 4 & 5 & 6 & 7 & 8 \\
\hline 1.Organizational Socialization & 1 & & & & & & & \\
\hline 2. Organizational Performance &, $611^{* *}$ & 1 & & & & & & \\
\hline 3.History & $789^{* *}$ & $477^{* *}$ & 1 & & & & & \\
\hline 4. Language & $668^{* *}$ & $503^{* *}$ &, $523^{* *}$ & 1 & & & & \\
\hline 5.Politics & $836^{* *}$ & $469^{* *}$ &, $594^{* *}$ & $487^{* *}$ & 1 & & & \\
\hline 6.People & $701^{* *}$ & $457^{* *}$ & $516^{* *}$ & $449^{* *}$ &, $513^{* *}$ & 1 & & \\
\hline 7. Organizational Goals and Values &, $821^{* *}$ & $494^{* *}$ &, $540^{* *}$ & $444^{* *}$ &, $588^{* *}$ & $454^{* *}$ & 1 & \\
\hline 8.Performance Proficiency &, $744^{* *}$ & $496^{* *}$ &, $509^{* *}$ &, $567^{* *}$ &, $533^{* *}$ & $448^{* *}$ & $478^{* * *}$ & 1 \\
\hline
\end{tabular}
$* *: \mathrm{p}<.05$

According to the results listed in Table 5, it is observed that there is a moderately significant, positive relation between organizational socialization and organizational performance $(\mathrm{r}=0,611, \mathrm{p}<.05)$. In other words, as socialization process in organization develops, it influences organizational performance positively. There is a significant, moderate, positive correlation between organizational performance and the factors of organizational socialization: History $(r=0,477, p<.05)$, Language $(r=0,503, \mathrm{p}<.05)$, Politics $(\mathrm{r}=0,469, \mathrm{p}<.05)$, People $(\mathrm{r}=0,457, \mathrm{p}<.05)$, Organizational Goals and Values $(\mathrm{r}=0,494, \mathrm{p}<.05)$ and Performance Proficiency $(\mathrm{r}=0,496, \mathrm{p}<.05)$.

Table 6. Multiple Regression Results of Organizational Performance Prediction

\begin{tabular}{|c|c|c|c|c|c|c|c|c|}
\hline Variable & B & ${\text { St. } \text { Error }_{B}}$ & & B & $\mathbf{T}$ & p & Dual $\mathbf{r}$ & Partial $\mathbf{r}$ \\
\hline Constant & 55,499 & 16,294 & - & & 11,601 & 000 & - & - \\
\hline History & 1,331 & 0,924 &, 088 & & 2,074 & 039 & 477 &, 081 \\
\hline Language & 4,079 & 1,851 & , 194 & & 4,856 & ,000 & ,503 &, 187 \\
\hline Politics & 0,748 & 0,664 & ,055 & & 1,267 & ,205 & ,469 & , 050 \\
\hline People & 1,813 & 0,948 & 140 & & 3,652 &, 000 & ,457 &, 142 \\
\hline $\begin{array}{l}\text { Organziational Goals and } \\
\text { Values }\end{array}$ & 1,165 & 0,539 & , 188 & & 4,671 &, 000 & ,494 &, 180 \\
\hline Performance Proficiency & 1,509 & 0,762 &, 159 & & 3,918 &, 000 & ,496 &, 152 \\
\hline $\begin{array}{l}\mathrm{R}=0,633 \\
\mathrm{~F}_{(6,649)=72,348}\end{array}$ & $\begin{array}{l}R^{2}=0,4 \\
p=0,00\end{array}$ & & & & & & & \\
\hline
\end{tabular}

$\mathrm{p}<.05$

The regression analysis results of organizational performance prediction are given in Table 6. During the analysis of dual and partial correlations between dependent variables and predictor variables, it was estimated that there was a moderate, positive relationship ( $\mathrm{r}=.477)$ between history and performance and the correlation between the two variables was calculated as $r=.081$. A moderate, positive correlation between the language factor and performance was found $\mathrm{r}=.503$ and the correlation between the two variables was found $\mathrm{r}=.187$. There was a moderate, positive correlation $(r=.469)$ between politics and performance and the correlation between the two variables was found $r=.050$. There was a moderate, positive correlation $(\mathrm{r}=.457)$ between people and performance and the correlation between the two variables was calculated as $r=.142$. There was a moderate, positive correlation $(r=.494)$ between organizational goals and values and performance and the correlation between the two variables was found $r=.180$. There was a moderate, positive correlation $(r=.496)$ between Performance Proficiency (PP) and performance and the correlation between the two variables was found $\mathrm{r}=.152$. It was observed that there was a moderate, positive correlation between the organizational socialization factors and the organizational performance scores $\left(\mathrm{R}=0,633, \mathrm{R}^{2}=0,401, \mathrm{p}<.05\right)$. The organizational socialization factors explained approximately $40 \%$ of total variance in organizational performance.

\section{Dscussion and Conclusion}

The participant secondary school teachers highly agreed with the factors of organizational socialization. They agreed with the following factors respectively: language (the most agreed), performance proficiency, people, history, organizational goals and values and politics (the least agreed). This case shows that teachers' socialization levels are high in all organizational socialization factors.

Secondary school teachers who rated the organizational performance scale items are quite high. The most agreed three items are; "I encourage an atmosphere of mutual respect and politeness", "I abide by class hour schedules" and "I give examples when suitable; I express concepts and ideas and make explanations in other manners". The least agreed three items are; "I make contact information accessible to all students (I share my working hours, phone number and e-mail address)", "I encourage contact/interaction" (I recommend students to call me, send me e-mails or set an appointment with me) and "I expect a high level of academic performance".

The socialization levels of the teachers indicate significant differences in history according to gender. The participant female teachers have higher levels in history than the males. Similarly, the socialization levels in language indicate 
significant differences according to gender. The participant female teachers have higher levels in language than the males.

Significant differences in socialization levels of teachers according to type of school are determined. In all the socialization factors, the private school teachers have been found to be more socialized than the public school teachers.

The organizational performance levels of the secondary school teachers significantly vary according to gender. The organizational performance levels of the female teachers are higher than those of the male participants. According to type of school, significant differences in the organizational performance levels have been observed. The performance of the private schools teachers is relatively higher than that of those in public schools. The teacher performance levels do not indicate significant differences according to postgraduate education.

There is a significant, moderate positive relationship between organizational socialization and organizational performance. Similarly, there is a significant, moderate positive relationship between the factors of organizational socialization (history, and language, politics, people, organizational goals and values, and performance proficiency) and organizational performance.

There is a significant, moderate positive relationship between the factors of organizational socialization (predictor variables) and organizational performance (predicted variable). All the factors explain approximately $40 \%$ of total variance in organizational performance.

In the history and language factors of organizational socialization, a significant difference has been concluded according to gender. The female teachers have higher levels in history and language than the male participants. According to Manning (1971), organization members need to learn the organization language in order to interpret information provided by others as well as an effective communication establishment (cited by Chao et al., 1994). However, females are found to be more talented in this aspect than male members. Accordingly, it is concluded that female teachers have higher emotional skills and develop better and friendlier relationships than male teachers (Krips, Lehtsaar, \& Kukemelk, 2011).

Schein (1968) suggests that awareness of organizational background besides personal background helps employees to decide appropriate manners in some cases. The research concludes that female teachers tend to know more and concerned about organizational background than male colleagues. There is no significant difference between the male and female participants in the following factors of organizational socialization: politics, people, organizational goals and values and performance proficiency. On the other hand, their organizational performance levels vary according to gender. Contrary to general belief, the participant female teachers' organizational performance has been found to be better than the males. Some studies have shown that expecting male performance to be better than a female's is discrimination, beyond a bias. Buchanan (2014) has concluded that males with liberal attitudes are inclined to evaluate female performance less discriminatorily than others. Joardar (2014) has shown that gender does not influence professional performance, whereas foreignness affects performance of male and female entrepreneurs differently. According to the research results, female entrepreneurs have more drawbacks on international scale than males.

There have been studies conducted to determine whether teachers' socialization perceptions vary according to gender. Buono and Kamm (1983) and Dodd, McCue and Wright (1996) have shown that female socialization process is adversely affected as organizational tasks are of secondary importance for female employees due to their private lives. Similarly, Singhapakdi, Sirgy, Lee, Senasu, Yu and Nisius (2014) have concluded that Asian female executives experience socialization less than male managers. On the other hand, in certain studies, results have indicated that females tend to socialize more than males in the workplace (Javidan, Bemmels, Stratton-Devine, \& Dastmalchian, 1995). Research has shown that strongly distinctive personality characteristics according to gender are assertiveness and mild-manners. Males tend to have more self-confidence than females, while females display milder manners than males (Feingold, 1994). This finding may allow one to conclude that males need less socialization than females because of excessive assertiveness. In a study, Ghazali (2011) has shown that organizational socialization does not significantly vary according to gender. As a result, it is obvious that further research in different cultures and professions is needed to obtain parallel findings to decide whether organizational socialization varies according to gender.

The research has concluded when compared to public school teachers, private school teachers attach more importance to organizational socialization in the following factors: history and language, people, politics, organizational goals and values and performance proficiency. Khan, Chandio and Farooqi (2014) have shown that private schools are more efficient in performance evaluation than public schools.

According to the research, teachers' organizational performances significantly vary according to type of school. However, there have been no significant differences observed in organizational socialization factors and organizational performance according to postgraduate education. Yet, the participant teachers' levels in the factor of organizational 
goals and values, and performance levels do not vary according to seniority. According to this result, performance levels and socialization levels in organizational goals and values of those with professional experience of 1-10 years are found to be higher than the levels of those with professional experience of 11-20 years. This case may be interpreted as those with lower seniority care more about organizational goals and values than the ones who have higher seniority. On the other hand, Hanif, Tariq and Nadeem (2011) have suggested that gender, school system, professional experience and age are significant predictors of teacher performance. Justine (2011) claims that teachers' experience and education are correlated with better performance in school.

The research has conluded that there is a significant, moderate positive correlation between organizational socialization factors and organizational performance. Accordingly, organizational performance will improve as socialization process increases in organizations. Regression analysis indicates that both organizational socialization and its factors are significant predictors of organizational performance. Vinsova, Komarkova, Kral, Tripes and Pirozek (2013) suggest that the organizational socialization process plays an important role in the development of organizational culture and thus leads to an increase in organizational performance. In their study, Malikeh, Mehdi and Mahmood (2011) have shown that socialization in organizations is a life-time process and it has a direct effect on employee performance. Similarly, Wang, Lin and Yang (2011) indicate that there is a significant relationship between organizational socialization and job satisfaction, and between organizational commitment and professional performance. Polatcan and Saylik (2015) have shown that organizational socialization has a great influence on commitment. On the other hand, Yanfei, Xi and Fantiani (2011) have concluded that socialization and performance are associated with a feeling of belonging. This result and the other findings reveal that organizational socialization of teachers should be emphasized if they are expected to improve their performance. There is no doubt that socialization will involve both better accumulation of professional knowledge, skills and perspectives and a school adaptation oriented learning process in educational organizations.

\section{Recommendations}

Numerous forms of socialization content attitudes categorized in the study under six factors (performance proficiency, politics and language, people, organizational goals and values, history) reflect the construct characteristics empirically identified by Chao et al. (1994). A considerable number of studies have been conducted for non- educational organizations besides a great number of performance studies. As a result, socialization and performance studies conducted for schools should be of critical importance in terms of improved school effectiveness. Finally, positive organizational outcomes such as organizational performance improvement, an increase in academic achievement and the prevention of teacher withdrawals must be elaboratively examined.

\section{References}

Ashforth, B. E., \& Saks, A. M. (1996). Socialization tactics: longitudinal effects on newcomer adjustment. Academy of Management Journal, 39, 149-178. http://dx.doi.org/10.2307/256634

Balc1, A. (2003). Örgütsel sosyalleşme: Kuram, strateji ve taktikler [Organizational socialization: Theory, strategy and tactics]. PegemA Yayınc1lik: Ankara.

Balc1, A. (2013). Sosyal bilimlerde araştırma: Yöntem teknik ve ilkeler [Research in social sciences: Methods, technics and principles]. Ankara: Pegem Akademi Yayıncilık.

Bauer, T. N., Morrison, E. W., \& Callister, R. R. (1998). Organizational socialization: A review and directions for future research. In G.R. Ferris (Ed.), Research in Personnel and Human Resources Management, 16, 149-214.

Buchanan, T. (2014). The influence of gender role attitudes on perceptions of women's work performance and the importance of fair pay. Sociological Spectrum, 34, 203-221. http://dx.doi.org/10.1080/02732173.2014.895637

Buono, A. F., \& Kamm, J. B. (1983). Marginality and the organizational socialization of female managers. Human Relations, 36(12), 1125-1140. http://dx.doi.org/10.1177/001872678303601204

Chao, G. T., O’Leary-Kelly, A. M., Wolf, S., Klein, H. J., \& Gardner, P. D. (1994). Organizational socialization: Its content and consequences. Journal of Applied Psychology, 79(5), 730-743. http://dx.doi.org/10.1037/0021-9010.79.5.730

Cokluk, O., Sekercioglu, G., \& Buyukozturk, S. (2010). Sosyal bilimler icin cok degiskenli istatistik [Multivariate statistics for social sciences]. Ankara: Pegem Akademi Yayincilik.

Dodd-McCue, D., \& Wright, G. B. (1996). Men, women, and attitudinal commitment: The effects of workplace experiences and socialization. Human Relations, 49(8), 1065-1091.

http://dx.doi.org/10.1177/001872679604900803 
Feingold, A. (1994). Gender differences in personality: A meta- analysis. Psychological Bulletin, 116(3), 429-456. http://dx.doi.org/10.1037/0033-2909.116.3.429

Feldman, D. C. (1976). A contingency theory of socialization. Administrative Science Quarterly, 21, 433-452. http://dx.doi.org/10.2307/2391853

Feldman, D. C. (1981). The multiple socialization of organization members. Academy of Management Review, 6(2), 309-319. http://dx.doi.org/10.2307/257888

Feldman, D. C. (1988). Managing careers in organizations. Glenview, IL: Scott Foresman.

Fisher, C. D. (1986). Organizational socialization: An integrative view. Research in Personnel and Human Resources Management, 4, 101-145.

Ghazali, Z. (2011). The influence of socialization agents and demographic profiles on brand consciousness. International Journal of Management and Marketing Research, 4(1), 19-29.

Hanif, R., Tariq, S., \& Nadeem, M. (2011). Personal and job related predictors of teacher stress and job performance among school teachers. Pakistan Journal of Commerce \& Social Sciences, 5(2), 319-329.

Javidan, M., Bemmels, B., Stratton-Devine, K., \& Dastmalchian, A. (1995). Superior and subordinate gender and the acceptance of superiors as role models. Human Relations, 48, 1271-1284. http://dx.doi.org/10.1177/001872679504801102

Joardar, A. (2014). The impact of foreignness on the relationship between gender and entrepreneur performance. Journal of General Management, 39(3), 17-37.

Johns, G., \& Saks, A. M. (2005). Organizational behaviour: Understanding and managing life at work. (6th Edition). Pearson Prentice Hall: Toronto.

Justine, N. (2011). Motivational practices and teacher's performance in jinja municipality secondary schools, jinja district, uganda. Bugema University, Master of Arts in Educational Management, Kampala, Uganda.

Khan, H. M. A., Chandio, J. H., \& Farooqi, M. T. K. (2014). Comparison of performance appraisal system in public and private schools. Pakistan Journal of Commerce and Social Sciences, 8(1), 272-278.

Krips, H., Lehtsaar, T., \& Kukemelk, H. (2011). About the differences of teachers' self- perceptions to the statements of social competence. US- China Education Review, B1, 139-149.

Malikeh, B., Mehdi, R., \& Mahmood, N. M. (2011). Study of organizational socialization and its relationship on employees' performance. African Journal of Business Management, 5(26), 10540-10544.

Manning, P. K. (1971). Talking and becoming: a view of organizational socialization. In J. D. Douglas (Ed.), Understanding Everyday Life: Toward the Reconstruction of Sociological Knowledge. London: Routledge and Kegan Paul.

Norton, S. (1994). Differences in perceptions of the organizational socialization process among subgroups of beginning principals in Louisiana. A paper presented at the annual meeting of the Mid- South Educational Research Association, (Nashville, TN, November 10, 1994, EA 026194.

Okon B. A., Frank, A., \& Antigha B. U. (2012). Industrial socialization and role performance in contemporary organization. International Journal of Business, Humanities and Technology, 2(5), 129-136.

Ostroff, C., \& Kozlowski, S. W. J. (1992). Organization socialization as a learning process: The role of information acquisition. Personnel Psychology, 45, 849-874. http://dx.doi.org/10.1111/j.1744-6570.1992.tb00971.x

Polatcan, M., \& Saylık A. (2015). The impact of the level of secondary education teachers' organizational socialization on organizational commitment. Mevlana International Journal of Education (MIJE), 5(2), 13-30.

Porter, L. W., Lawler, E. E., \& Hackman. J. R. (1975). Behavior in organizations. New York: McGraw-Hill.

Reichers, A. E. (1987). An interactionist perspective on newcomer socialization rates. Academy of Management Review, 12, 278-287.

Robbins, S. P. (2005). Organizational behavior, (11th Edition). Pearson Prentice Hall: New Jersey.

Saks, A. M., \& Ashforth, B. E. (1997). A longitudinal investigation of the relationships between job information sources, applicant perceptions of fit and work outcomes. Personnel Psychology, 50(2), 395-426. http://dx.doi.org/10.1111/j.1744-6570.1997.tb00913.x

Schein, E. H. (1968). Organizational socialization and the profession of management. Industrial Management Review, 9 , $1-15$. 
Schein, E. H. (1990). Organizational culture and leadership. San Francisco: Jossey-Bass.

Singhapakdi, A., Sirgy, M. J., Lee, D. J., Senasu, K., Yu, G. B., \& Nisius, A. M. (2014). Gender disparity in job satisfaction of western versus Asian managers. Journal of Business Research, 67, 1257-1266. http://dx.doi.org/10.1016/j.jbusres.2013.04.004

Smith, D. M. (1989). Organizational socialization of physical therapists. Physical Theraphy, 69(4), 40-44.

Taormina, R. J. (2004). Convergent validation of two measures of organizational socialization. International Journal of Human Resource Management, 15, 76-94. http://dx.doi.org/10.1080/0958519032000157357

Taormina, R. J. (2009). Organizational socialization: the missing link between employee needs and organizational culture. Journal of Managerial Psychology, 24(7), 650- 676. http://dx.doi.org/10.1108/02683940910989039

Torrington, D., \& Hall, L. (1995). Personnel management: HRM in action. Prentice Hall International (UK) Ltd, Hemel Hempstead.

Van Maanen, J., \& Schein, E. H. (1979). Toward of theory of organizational socialization. Research in Organizational Behavior, 1, 209-264.

Van Maanen, J. (1975). Police socialization: a longitudinal examination of job attitudes in an urban police department. Administrative Science Quarterly, 20(2), 207-228. http://dx.doi.org/10.2307/2391695

Van Maanen, J. (1978). People processing: strategies of organizational socialization. Organizational Dynamics, 7(1), 18-36. http://dx.doi.org/10.1016/0090-2616(78)90032-3

Vinsova, T., Komarkova, L., Kral, P., Tripes, S., \& Pirozek, P. (2013). The Process of socialization in relation to organizational performance. Retrieved from

http://eds.a.ebscohost.com/eds/pdfviewer/pdfviewer?vid=2\&sid=ef62b84b-d598-4bba-a3a7-5d2f4c306233\%40ses sionmgr4003\&hid $=4208$ on 01.06 .2014

Wang, Y., Lin, G., \& Yang, Y. (2011). Organizational socialization and employee job performance: An examination on the role of the job satisfaction and organizational commitment. A paper presented In Service Systems and Service Management (ICSSSM), 2011 8th International Conference on IEEE, Tianjin.

Wanous, J. P. (1980). Organizational entry: Recruitment, selection and socialization of newcomers. Readings, M.A.: Addison-Wesley.

Wharton County Junior College Faculty Self- Evaluation Form, Retrieved from http://www.wcjc.edu/About-Us/administration/offices/human-resourses/documents/Appendix-I-Faculty-Evaluation -System-General-Information.pdf on 21.07.2014

Wiese, D. S., \& Buckley, M. R. (1998). The evolution of the performance appraisal process. Journal of Management Organizational background, 4(3), 233-249. http://dx.doi.org/10.1108/13552529810231003

Yanfei, W., Xi, H., \& Fantiani, Z. (2011). An empirical study on interactional relationship among psychological ownership, organizational socialization and employees performance. A paper presented in International Management and Service Science Conference (MASS), Wuhan.

This work is licensed under a Creative Commons Attribution 3.0 License. 